\title{
Germination rate and emergence success in bluebunch wheatgrass
}

\author{
STANLEY G. KITCHEN AND STEPHEN B. MONSEN
}

\begin{abstract}
Authors are botanists at the Intermountain Research Station, Forest Service, USDA, located at the Shrub Sciences Laboratory, 735 North 500 East, Provo, Ut. 84606.
\end{abstract}

\begin{abstract}
Development of plant materials adapted to the demands of a harsh environment and conditions created by standard planting practices has resulted in improved seedling establishment for some species. Bluebunch wheatgrass (Pseudoroegneria spicata [Pursh] Love) is an important native bunchgrass often planted in the Intermountain and Pacific Northwest regions. Though cultivars have been developed, this species continues to have a reputation for weak seedlings. Forty-seven accessions of bluebunch wheatgrass collected from naturally occurring populations in 9 geographic regions and the cultivar 'Goldar' were evaluated for germination rate, seedling emergence and growth, and seed weight. Significant differences in seed weight and germination rate at optimum $\left(15 / 25^{\circ} \mathrm{C}\right)$ and cold $\left(1^{\circ} \mathrm{C}\right)$ temperatures were observed. Seedling emergence from a $4-\mathrm{cm}$ depth ranged from 5 to $66 \%$. Mean dry shoot weight 28 days after planting varied among accessions by a factor of 6 . Simple correlations between seed weight and percentage emergence $(r=0.62)$ and seed weight and mean shoot weight $(r=0.63)$ indicate seed weight could be used as a preliminary screening test for these traits. Seed weight was not useful in predicting germination rate. Results suggest establishment success may be improved through careful selection for traits associated with seedling vigor.
\end{abstract}

Key Words: seedling vigor, Pseudoroegneria spicata, seed size, depth planting

Climatic conditions on western North American rangelands make establishment of perennial grasses a challenge. In the Great Basin and Columbia River Plateau, springtime seedbed moisture and temperature often undergo rapid change, resulting in a narrow window for seedling emergence and establishment. Research and experience have provided economical practices that increase the probability for establishment success. One such practice that enables seeds to make maximum use of winter moisture is fall planting. In addition, establishment is usually best if seeds are drilled rather than broadcast (Nelson et al. 1970). Buried seeds experience more favorable moisture and temperature conditions than seeds at the soil surface.

Researchers have selected plant species/ecotypes with growth characteristics suited for the seedbed conditions created by the interaction of the environment and the improved planting practices. Many of these selections have resulted in improved stand establishment, and the resulting cultivars are described as having good seedling vigor.

Bluebunch wheatgrass (Pseudoroegneria spicata [Pursh] Love)

This research was funded by the Bureau of Land Management, USDI, through Interagency Agreement ID910-IA-8. Special thanks are extended to Susan E. Meyer, Stephanie Carlson, Karl Soerensen, and Craig Walker for help in collecting and cleaning seeds and conducting laboratory and greenhouse work.

Manuscript accepted 24 Sept. 1993. is one of the more important grasses in the western United States and Canada. It occurs as a dominant in many areas of the Intermountain and Pacific Northwest regions. The use of bluebunch wheatgrass seed in revegetation efforts has not equalled that of most introduced species in part due to the commonly held belief that the species has weak seedlings (Jones et al. 1991).

Though probably no single characteristic can be used as a measure of seedling vigor in grasses, "a rapid germination rate, fast rates of root and top growth, a robust growth habit, [and] resistance to stress" may be important indicators (McKell 1972). Simple tests allow researchers to screen numerous populations for traits associated with establishment success. How useful these tests are depends upon how closely the traits are associated with successful stand establishment in the field.

A primary objective of this work was to measure variablity among collections of bluebunch wheatgrass representing a widespread geographic distribution. Particularly, we compared seed and seedling performance of the cultivar 'Goldar' to that of wild collections, using 'Hycrest' crested wheatgrass (Agropyron cristatum [L.] Gaertner $\times A$. desertorum [Fisher ex Link] Shultes) as a standard for all accessions. In addition, by correlating results of different tests, we assessed the usefulness of each test as a screening tool for seedling vigor in bluebunch wheatgrass.

\section{Materials and Methods}

Seeds for 47 naturally occurring populations of bluebunch wheatgrass, representing 9 geographic regions in 8 states, were collected during the summers of 1988 and 1989 (Table 1). Seed lots were cleaned using a small 2-screen fanning mill and stored in envelopes at room temperatures. Seed of the cultivar 'Goldar' (1987 harvest) was obtained from Soil Conservation Service Plant Material Centers at Aberdeen, Ida. 'Hycrest' crested wheatgrass (1989 harvest) seed was obtained from the Agricultural Research Service, USDA, in Logan, Ut. Seeds used for seed weight determination, germination, and emergence tests were hand selected to maximize the percentage of viable undamaged seed. Mean seed weight was determined for each collection using 4 subsamples of 100 seeds each. We converted values for grams per 100 seeds to number of seeds per gram for data presentation.

\section{Germination Experiments}

For each experiment, a subsample of 100 seeds of each collection was subdivided into 4 equal replications ( 25 seeds each). Seeds of each replication were placed in a $100 \times 15-\mathrm{mm}$ petri dish above 2 germination blotters (Anchor Paper Company) moistened to saturation with tap water. Petri dishes were randomly stacked in a cardboard box that was then enclosed in a plastic bag. The box was kept under controlled temperatures until the end of the experiment except for brief periods when the petri dishes were examined for data collection. During these periods, seeds were exposed to fluo- 
Table 1. Mean germination rate, emergence percentage, dry shoot weight (mg), and number of seeds per gram for 47 collections of bluebunch wheatgrass from naturally occurring populations and the cultivar 'Goldar'.

\begin{tabular}{|c|c|c|c|c|c|}
\hline \multirow{2}{*}{$\begin{array}{l}\text { Geographic region } \\
\text { county, state }\end{array}$} & \multicolumn{2}{|c|}{ Germination rate index } & \multicolumn{2}{|c|}{ Deep planting } & \multirow[b]{2}{*}{ Number of seeds/grama } \\
\hline & $15 / 25^{\circ} \mathrm{C}$ & $1^{\circ} \mathrm{C}$ & Emergence & Dry shoot weight & \\
\hline & & & $(\%)$ & $(\mathrm{mg})$ & \\
\hline \multicolumn{6}{|l|}{ Palouse Prairie } \\
\hline Asotin, WA (1) & 34.8 & 20.5 & 66 & 9.5 & 228 \\
\hline Asotin, WA (2) & 40.3 & 16.0 & 65 & 7.1 & 259 \\
\hline Garfield, WA (1) & 39.1 & 20.3 & 25 & 4.0 & 276 \\
\hline Garfield, WA (2) & 42.3 & 19.3 & 50 & 5.0 & 298 \\
\hline Whitman, WA & 38.5 & 16.6 & 53 & 5.7 & 255 \\
\hline Nez Perce, ID & 40.8 & 15.0 & 43 & 6.8 & 233 \\
\hline \multicolumn{6}{|l|}{ Snake River Canyon Area } \\
\hline Adams, ID* & 33.1 & - & 48 & 7.5 & 216 \\
\hline Idaho, ID (1) & 34.5 & 14.4 & 39 & 5.6 & 260 \\
\hline Idaho, ID (2) & 30.2 & 13.6 & 53 & 4.7 & 274 \\
\hline Idaho, ID (3) & 29.7 & 14.6 & 41 & 4.1 & 243 \\
\hline Washington, ID (1) & 33.3 & 14.3 & 43 & 7.2 & 176 \\
\hline Washington, ID (2)* & 30.4 & - & 16 & 2.5 & 240 \\
\hline Washington, ID (3) & 36.3 & 16.7 & 53 & 5.4 & 197 \\
\hline Baker, OR (1) & 33.9 & 13.3 & 38 & 5.6 & 196 \\
\hline Baker, OR (2) & 28.5 & 11.8 & 25 & 2.7 & 253 \\
\hline Baker, OR (3) & 31.7 & 12.8 & 58 & 5.7 & 176 \\
\hline Baker, OR (4) & 27.0 & 15.3 & 59 & 5.7 & 178 \\
\hline \multicolumn{6}{|l|}{ Snake River Plain } \\
\hline Ada, ID & 33.9 & 14.8 & 40 & 4.0 & 258 \\
\hline Butte, ID & 35.5 & 16.8 & 19 & 5.6 & 309 \\
\hline Clark, ID & 29.7 & 14.6 & 8 & 0.6 & 437 \\
\hline Owyhee, ID & 30.4 & 12.0 & 8 & 2.2 & 374 \\
\hline Malheur, OR & 25.2 & 11.0 & 20 & 2.4 & 264 \\
\hline \multicolumn{6}{|l|}{ Western Great Basin } \\
\hline Elko, NV & 27.0 & 13.1 & 24 & 3.4 & 262 \\
\hline Eureka, NV & 29.3 & 14.3 & 36 & 3.7 & 270 \\
\hline Humbolt, NV (1) & 32.7 & 10.6 & 22 & 3.4 & 323 \\
\hline Hombolt, NV (2) & 33.2 & 17.6 & 17 & 2.8 & 273 \\
\hline \multicolumn{6}{|l|}{ Eastern Great Basin } \\
\hline Bear Lake, ID & 32.7 & 14.2 & 25 & 2.7 & 376 \\
\hline Cache, UT & 28.0 & 12.5 & 39 & 3.8 & 344 \\
\hline Davis, UT (1) & 33.4 & 15.3 & 14 & 5.5 & 301 \\
\hline Davis, UT (2)** & 29.3 & 12.2 & - & - & 285 \\
\hline Juab, UT (1) & 29.8 & 15.0 & 14 & 3.5 & 343 \\
\hline Juab, UT (2) & 33.3 & 13.9 & 12 & 3.3 & 317 \\
\hline Juab, UT (3) & 31.5 & 13.0 & 5 & 5.5 & 403 \\
\hline Salt Lake, UT & 28.4 & 12.0 & 8 & 3.3 & 312 \\
\hline Utah, UT (1) & 25.9 & 12.6 & 15 & 3.0 & 432 \\
\hline Utah, UT (2) & 29.5 & 14.4 & 12 & 5.8 & 262 \\
\hline \multicolumn{6}{|l|}{ Salmon River Valley } \\
\hline Custer, ID & 40.1 & 18.1 & 28 & 2.7 & 352 \\
\hline Lemhi, ID & 46.5 & 17.5 & 44 & 7.3 & 279 \\
\hline \multicolumn{6}{|l|}{ Bitterroot River Valley } \\
\hline Missoula, MT & 36.8 & 12.3 & 55 & 4.7 & 254 \\
\hline Rovalli, MT & 37.6 & 15.3 & 39 & 3.6 & 237 \\
\hline \multicolumn{6}{|l|}{ Upper Colorado Plateau } \\
\hline Garfield, CO & 36.0 & 10.2 & 23 & 3.0 & 360 \\
\hline Moffat, $\mathrm{CO}$ & 33.5 & 11.0 & 58 & 4.3 & 356 \\
\hline Rio Blanco, CO & 33.0 & 10.8 & 34 & 3.9 & 356 \\
\hline Uinta, WY & 32.9 & 13.0 & 6 & 2.5 & 378 \\
\hline \multicolumn{6}{|l|}{ Colorado Front Range } \\
\hline Larimer, CO (1) & 31.2 & 10.9 & 8 & 1.6 & 375 \\
\hline Larimer, $C O(2)^{* *}$ & 26.1 & 9.6 & $\ldots$ & -1 & 403 \\
\hline Larmier, CO (3) & 33.3 & 14.1 & 21 & 2.5 & 318 \\
\hline \multicolumn{6}{|l|}{ Cutivar } \\
\hline 'Goldar' & 51.2 & 17.8 & 47 & 8.4 & 201 \\
\hline Overall mean & 33.4 & 14.2 & 32 & 4.4 & 291 \\
\hline
\end{tabular}

*The $1 \mathrm{C}$ germination rate test was omitted for these accessions due to insufficient seed numbers.

**These accessions were not used in the greenhouse emergence test. 
rescent light and additional water was added as needed. Seeds were classified as germinated when the radicle had elongated to at least 3 $\mathrm{mm}$ and the coleoptile had elongated and demonstrated a positive gravitropic response. Germinated seeds were counted and removed from the petri dish on each observation date. Abnormal seedlings (e.g., no radicle) were treated as nonviable.

The 2 experiments differed in temperature regime, duration of treatment, and frequency of observation dates. We designed the first experiment to determine germination rate under near-optimal conditions. In this test, seeds experienced a 12-hour alternating temperature regime of $15 / 25^{\circ} \mathrm{C}$ for 21 days. Data were collected on days $3,4,5,6,7,10,14$, and 21 . The second experiment tested germination rate at a constant $1^{\circ} \mathrm{C}$, a crude approximation of the temperature experienced by seeds under winter snowpack. Earliest germination was observed on day 38 . Germinants were scored and removed twice weekly from day 38 through day 84 . The box was then placed in the $15 / 25^{\circ} \mathrm{C}$ chamber for 7 days, after which any additional germinants were counted. Viability of ungerminated seeds was determined by cut test.

Germination rate indices (GR) were determined for replications of each accession at both temperature regimes. Modified versions of the method described by Maguire (1962) were used and are described as follows:

Experimental Temperature $15 / 25^{\circ} \mathrm{C}$

$\mathrm{GR}=(\mathrm{G} 3 / 1+\mathrm{G} 4 / 2+\mathrm{G} 5 / 3+\mathrm{G} 6 / 4+\mathrm{G} 7 / 5+\mathrm{G} 10 / 6+\mathrm{G} 14 / 7+$ $\mathrm{G} 21 / 8)$

Experiment Temperature $1^{\circ} \mathrm{C}$

$\mathrm{GR}=(\mathrm{G} 38 / 1+\mathrm{G} 42 / 2+\mathrm{G} 45 / 3+\mathrm{G} 49 / 4+\mathrm{G} 52 / 5+\mathrm{G} 56 / 6+$ $\mathrm{G} 59 / 7+\mathrm{G} 63 / 8+\mathrm{G} 66 / 9+\mathrm{G} 71 / 10+\mathrm{G} 77 / 11+\mathrm{G} 84 / 12)$

Where $G(n)$ equals the percentage of total viable seeds counted as germinated and removed on day $n$, and $n$ equals the number of days after initiation of the experiment.

\section{Depth Emergence Trials}

In June 1990 we evaluated emergence percentage and shoot growth rate in response to depth planting in loamy sand. Three replications of 50 seeds for each collection were planted uniformly in 70-cm rows. Rows of seeds were spaced $6 \mathrm{~cm}$ apart on top of 5.5 $\mathrm{cm}$ of firm level soil in 12 well-drained planter boxes $(80 \mathrm{~cm} \times 95$ $\mathrm{cm}$ ). Seeds were covered to a depth of $4.0 \mathrm{~cm}$. The soil was settled with water, and additional soil was added to make a uniform depth throughout each box. Boxes were watered frequently to ensure that water was not limiting. Boxes were kept on benches in a greenhouse with a $25 / 15^{\circ} \mathrm{C}$ day/night temperature regime. Overhead fluorescent lights provided supplemental light.

Emergence was monitored for 28 days after planting. We adjusted total emergence percentage using the viability percentages determined in the near-optimum temperature germination experiment as an estimate of total viable seed percentage. Mean dry shoot weight was determined for each row using up to 10 healthy plants for each replication. To do this, top growth was harvested, oven dried at $40^{\circ} \mathrm{C}$ for 24 hours, and weighed to the nearest $0.1 \mathrm{mg}$.

We subjected all data to analyses of variance and mean separations using the Student-Neuman-Keuls (SNK) method $(p<0.05)$. We used simple correlations to evaluate relationships among the different tests.

\section{Results}

We observed significant differences $(p<0.05)$ among collections in germination rate at both temperature regimes (Table 1). Bluebunch wheatgrass germination rate indices ranged from 25.2 to 51.2 at near-optimum temperatures $\left(15 / 25^{\circ} \mathrm{C}\right)$ and from 9.6 to 20.5 at near-freezing temperatures $\left(1^{\circ} \mathrm{C}\right)$. The correlation between germination rate at near-optimum and near-freezing temperatures

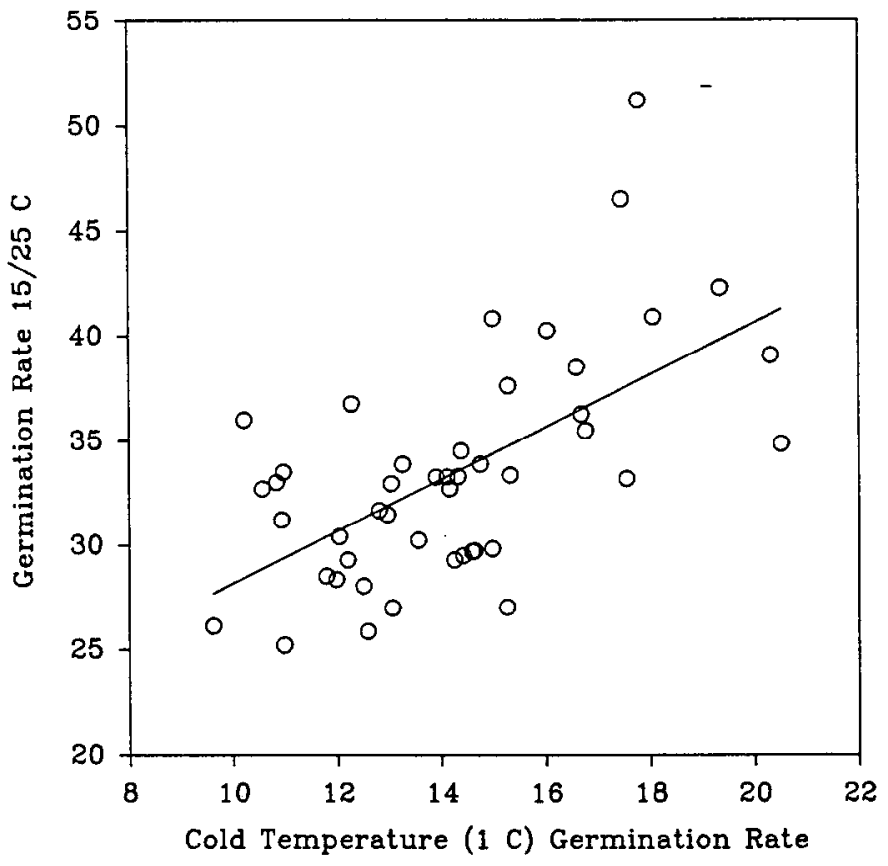

Fig. 1. The relationship between optimum $\left(15 / 25^{\circ} \mathrm{C}\right)$ and cold $\left(1^{\circ} \mathrm{C}\right)$ temperature germination rates. The equation for the plotted regression line is:

Optimum GR $\left(15 / 25^{\circ} \mathrm{C}\right)=1.19 \times$ Cold G R $\left(1^{\circ} \mathrm{C}\right)+16.48$

is significant but not as high as might be expected (Fig. 1). The cold temperature germination rate index of 'Hycrest' was 26.8, higher than that of any of the bluebunch wheatgrass collections. This was due to more rapid initiation of coleoptile growth. The radicle emergence rates of several bluebunch collections were higher than that of 'Hycrest' (data not shown). 'Goldar' had the highest germination rate index at optimum temperatures of all seed lots. High germination rates were most common among, but not limited to, collections from the Palouse Prairie. Mean viabilities for all collections in the near-optimum and cold temperature tests were 90 and $84 \%$, respectively. No dormant (ungerminated, viable) seeds were observed in either experiment.

Emergence of seed buried at a 4-cm depth varied from 5 to $66 \%$, and mean dry shoot weight ranged from 1.6 to $9.5 \mathrm{mg} /$ plant across all bluebunch wheatgrass collections (Table 1). 'Goldar' had 47\% emergence an $8.4 \mathrm{mg} /$ plant mean dry shoot weight. Emergence for 'Hycrest' was $69 \%$ but was not significantly different from that of the better lines of bluebunch wheatgrass. The high mean dry shoot weight (12.2 mg/plant) of 'Hycrest' suggests a faster seedling shoot growth rate for crested wheatgrass than for bluebunch wheatgrass.

At the conclusion of the experiment the soil along a number of seed rows was carefully removed to expose germinated seeds and seedlings. For successful emergence, the coleoptile apparently had to reach near the soil surface. We observed that plumules which emerged from subsurface coleoptiles were frequently damaged.

There were differences among collections from different geographic regions (Table 1). Mean emergence percentages for collections from the Palouse Prairie and the Snake River Canyon regions were 50 and $43 \%$, respectively. Conversely, mean emergence for collections from the Eastern Great Basin was $16 \%$. Mean dry shoot weight was highest among collections from the Palouse Prairie (6.4 $\mathrm{mg}$ / plant) and lowest among collections from the Colorado Front Range ( $2.1 \mathrm{mg} /$ plant). A simple correlation between emergence percentage and mean dry shoot weight demonstrates patterns among major geographical regions (Fig. 2).

Seed weight ranged from 176 to 437 seeds/g (Table 1). The 
- Palouse Prairie - Snake River Canyon Area

$\nabla$ Salmon River Valley $\checkmark$ Bitterroot River Valley

- Snake River Plain - Western Great Basin

$\Delta$ Eastern Great Basin 4 Upper Colorado Plateau

- Colorado Front Range

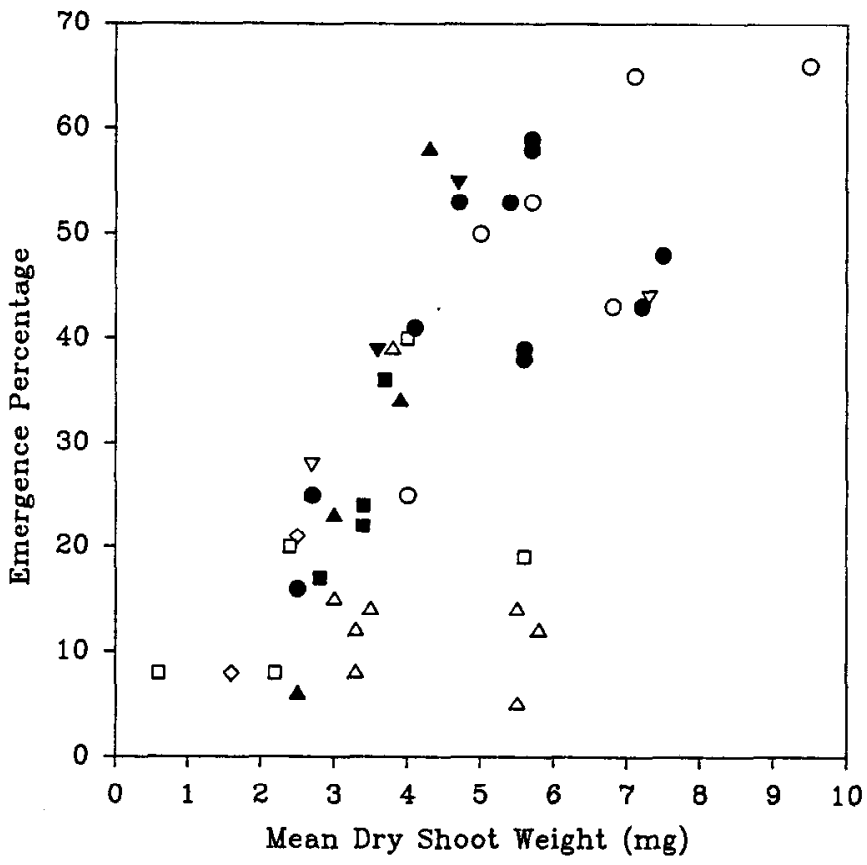

Fig. 2. The relationship between emergence percentage and mean shoot weight results of the deep planting experiment. Results of collections from 8 geographic regions are distinguished for comparison purposes.

collections with the heaviest seeds were primarily from the Snake River Canyon region. No clear regional patterns emerged for seeds with medium-range weights. Although the seeds of the Colorado Plateau and Colorado Front Range collections are all relatively light (mean of 364 seeds/g), there were numerous collections from other geographic regions with similar seed weights. 'Goldar' seed (201 seeds/g), though significantly lighter than the seeds of 3 wild collections, was nevertheless among the heaviest.

Table 2. Simple correlation coefficients ( $r$ ) among seed weights, germination rates at 2 temperatures, and emergence percentage and mean shoot mass in response to deep planting.

\begin{tabular}{|c|c|c|c|c|}
\hline & \multirow{2}{*}{\multicolumn{2}{|c|}{ Germination rate }} & \multicolumn{2}{|c|}{ Deep planting } \\
\hline & & & \multirow{2}{*}{$\begin{array}{c}\% \\
\text { Emergence }\end{array}$} & \multirow{2}{*}{$\begin{array}{c}\text { Mean } \\
\text { shoot wt. }\end{array}$} \\
\hline & $15 / 25^{\circ} \mathrm{C}$ & $1^{\circ} \mathrm{C}$ & & \\
\hline Seed weight & 0.26 & 0.37 & $0.62^{*}$ & $0.63^{*}$ \\
\hline $\begin{array}{l}\text { Germination rate } \\
15 / 25^{\circ} \mathrm{C} \\
1^{\circ} \mathrm{C}\end{array}$ & - & $\underline{0.60^{*}}$ & $\begin{array}{l}0.39 \\
0.32\end{array}$ & $\begin{array}{l}0.50^{*} \\
0.53^{*}\end{array}$ \\
\hline Emergence percentage & - & - & - & $0.68^{*}$ \\
\hline
\end{tabular}

*Significant at 0.01 level.

We calculated simple correlations in examining the relationships between seed weight, germination rates, and responses to deep planting (Table 2). Seed weight was not significantly correlated with germination rate $(p<0.01)$. Significant correlations were observed between seed weight and emergence percentage and seed weight and mean dry shoot weight (Fig. 3). Germination rates at either temperature regime were not significantly correlated with emergence percentage; there was a higher correlation with mean
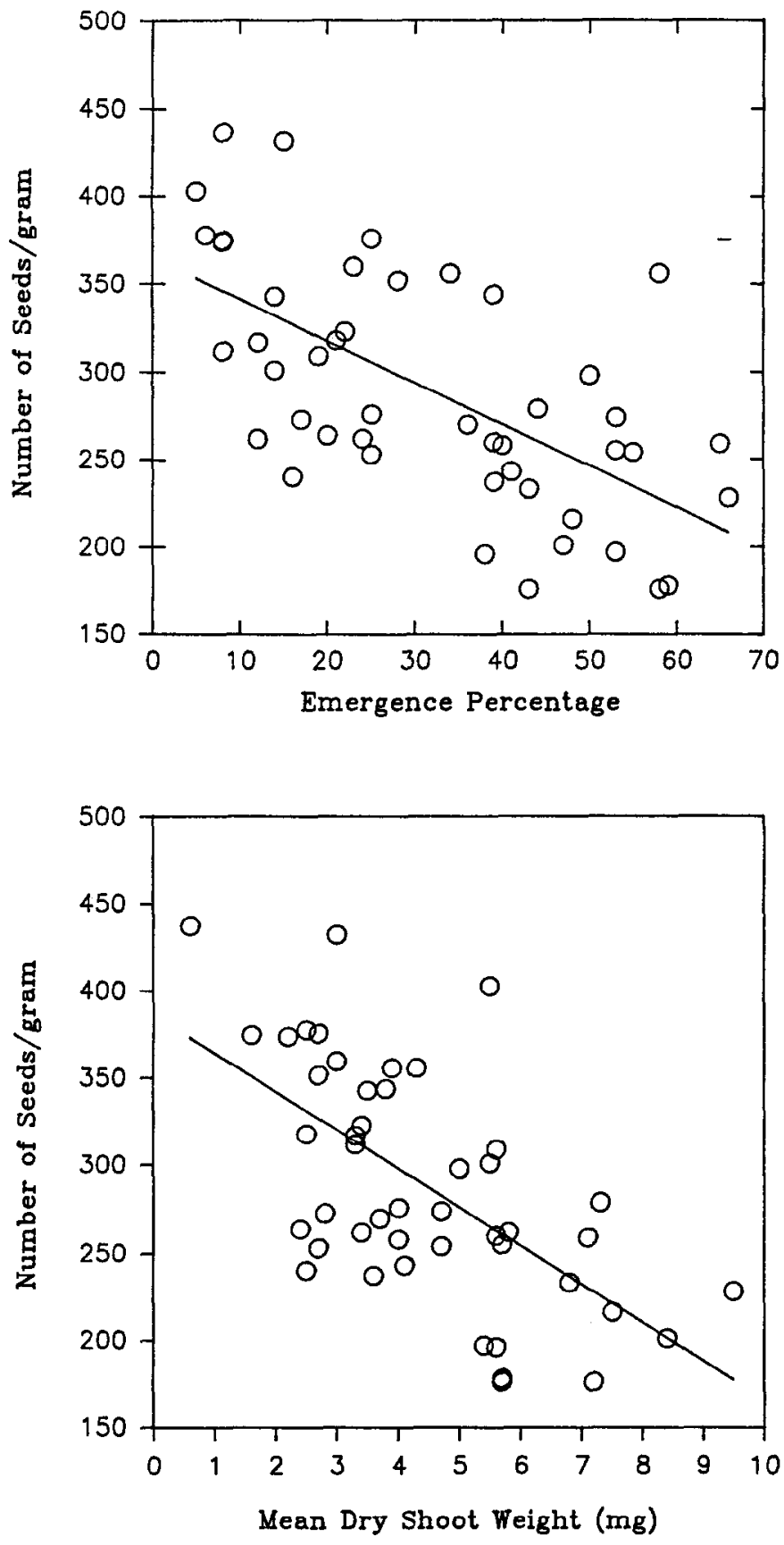

Fig. 3. The relationships between seed size (number of seeds per gram) and the results of the deep seeding trial expressed as emergence percentage and mean dry shoot weight ( $\mathrm{mg}$ ). The equation for the plotted regression lines are:

(A) Seeds per gram + -2.38 $\times$ Emergence Percentage +365.1

(B) Seeds per gram $+-22.07 \times$ Mean Dry Shoot Weight +386.56

dry shoot weight.

We observed considerable variation in seed weight, germination rate, and responses to deep planting among the bluebunch wheatgrass collections. Some traits revealed regional patterns suggesting adaptation to broad climatic patterns. Simple correlations were highest between seed weight and emergence percentage, seed weight and mean shoot weight, and emergence percentage and mean shoot weight (Table 2).

\section{Discussion}

Maguire (1962) suggested that germination rate of nondormant 
seeds could be used as a simple method for evaluating seedling vigor of forage grasses. Subsequently, Lawrence (1963) found that germination rate was correlated with other measures of seedling vigor among collections of Russian wildrye (Psathyrostachys juncea [Fischer] Nevski). However, the differences we observed among bluebunch wheatgrass collections in germination rate were not highly correlated with other measures of seedling vigor.

Germination rate from low temperature tests is likely to be more useful than germination rate from tests conducted at optimum temperatures. Cold temperature germination tests more closely resemble field conditions when seedling emergence is likely to take place. In addition, differences in germination rate are magnified at lower temperatures, permitting easier segregation of study lines. Finally, these tests are easily performed on large numbers of seed lots. Based on our results, this test should not be substituted by any other test.

In our work, the delay in germination caused by cold temperatures was not expressed equally by all collections. This may reflect relative differences in the levels of risk from spring frost and drought among widely separated collection sites. Climate correlated differences in cold temperature germination rate exist for other species common to bluebunch wheatgrass habitat (McArthur et al. 1987, Meyer et al. 1989, Kitchen and Meyer 1991, Meyer and Monsen 1991).

Another frequently used indicator of seedling vigor in grasses is growth response to deep planting. Planting depth is determined by the growth medium and species being evaluated (Murphy and Arny 1939). Emergence percentage, shoot size, and overall vigor are the primary variables measured (McKell 1972). These tests are usually conducted in greenhouses or growth chambers where temperature and moisture regimes are controlled and set at levels favorable for rapid growth. Parallel field tests are frequently conducted as well. Significant correlations have been observed between the results of deep seeding and field tests among lines of several species including intermediate wheatgrass (Thinopyron intermedium [Host] Barkworth \& D. Dewey) (Hunt and Miller 1965) and Russian wildrye (Asay and Johnson 1980, Berdahl and Barker 1984). Given the range of response of our bluebunch wheatgrass collections to this test, screening of study lines by deep planting should yield positive results.

For many species, the ability to emerge from a deep planting is dependent upon maximum coleoptile length (Rogler 1954, Berdahl and Barker 1984). This trait is easy to measure and probably under strong genetic control (Hunt and Miller 1965). It may be feasible to use maximum coleoptile length in place of emergence from deep planting, as this characteristic was primarily responsible for bluebunch wheatgrass emergence success. However, this approach does not provide information on shoot growth rate. In addition, any test that could easily provide root growth data (both weight and maximum length) would be valuable (Harris 1970, 1977). DeWitt (1969) observed considerable variability in early root growth responses to cold temperatures among collections of bluebunch wheatgrass.

Seed size is the easiest and perhaps the most common characteristic used to screen for seedling vigor in grasses. Positive correlations between seed size and field establishment, and seed size and other greenhouse and laboratory tests for seedling vigor have been documented for numerous species (Rogler 1954, Kneebone and Cremer 1955, Tossell 1960, Vogel 1963, Hunt and Miller 1965, Asay and Johnson 1980, Asay and Johnson 1983, Berdahl and Barker 1984). Simple correlations (Table 2) revealed little relationship between seed weight and either test of germination rate for bluebunch wheatgrass. Seed weight was a fairly good predictor of emergence percentage and mean shoot weight from deep planting (Fig. 3).
Some researchers suggest seed size be used only in "first cut" phases of cultivar selection and that advanced selections rely on performance-based evaluations (Asay and Johnson 1983, Berdahl and Barker 1984). Our data support this position.

Selecting for seedling vigor in bluebunch wheatgrass will only be effective to the extent differences among seed collections are genetic. However, other possible causes of variable performance exist among the collections in these studies. For example, the collections were taken from widely distributed "wild" populations that had considerable differences in maternal environment during seed production. In addition, seeds collected during 2 seasons were different in age at the time the tests were conducted. The degree to which such environmental differences affect these test results cannot be determined in this study. However, as supported by work with other species, there is good reason to believe that genetic control should be relatively strong (Hunt and Miller 1965, Asay and Johnson 1983). Thus, the opportunity is likely that seedling vigor will improve in bluebunch wheatgrass through evaluation and selection.

When evaluating large numbers of breeding lines, it is imperative to eliminate as many lines as possible using simple tests prior to intensive field testing. However, using an inappropriate level of selection intensity may result in the elimination of lines that may have superior field performance capabilities. The decision about what level of selection intensity to use must be guided by how closely the test results are related to actual desired traits. For this reason, the use of multiple tests in evaluating lines of bluebunch wheatgrass appears to be worth the extra effort. Certainly, the results of these and all other tests of seedling vigor must be more thoroughly compared to parallel field plantings.

Though a few accessions of bluebunch wheatgrass had emergence percentages not significantly different from that of 'Hycrest', shoot growth was not as rapid for any bluebunch wheatgrass collection. This suggests that seedings of potential cultivars of this species may require more time to reach maturity than those of crested wheatgrass. Improvement in this and other desirable traits will likely come with intense selection within segregating populations.

We recognize that poor performance in these trials does not necessarly indicate weak establishment attributes under natural conditions. For example, seeds of bluebunch wheatgrass ripen and disperse during mid to late summer and are able to fall-germinate and emerge with adequate moisture. Seeds drilled in late fall experience a sequence of conditions quite different from that experienced by seeds in natural plantings. Traits that improve establishment under these conditions may have less importance in natural regeneration. However, unless we are willing to rethink our established planting practices, we must select for those traits that ensure the greatest probability of establishment success using standard planting practices. Some plant material selections may possess attributes that are desirable enough to justify such consideration.

We recommend selection for seedling vigor within accessions of bluebunch wheatgrass with other favorable characteristics, particularly drought tolerance. The heritable variation necessary to do this successfully is apparently available. We also recommend a more careful examination of the seedbed requirements of these species and the impacts of modifying traditional seeding practices.

\section{Literature Cited}

Asay, K.H. and D.A. Johnson. 1980. Screening for improved stand establishment in Russian wild ryegrass. Can. J. Plant Sci. 60:1171-1177.

Asay, K.H. and D.A. Johnson. 1983. Genetic variability for characters affecting stand establishment in crested wheatgrass. J. Range Manage. 36:703-706. 
Berdahl, J.D., and R.E. Barker. 1984. Selection for improved seedling vigor in Russian wildrye. Can. J. Plant Sci. 64:131-138.

DeWitt, F.P. 1969. Early developmental response to low temperature in Agropyron spicatum collected from native stands in western North America. M.S. Thesis, Washington State Univ., Pullman.

Harris, G.A. 1970. Competition for moisture among seedlings of annual and perennial grasses as influenced by root elongation at low temperatures. Ecology 51:530-534.

Harris, G.A. 1977. Root phenology as a factor of competition among grass seedlings. J. Range Manage. 30:172-177.

Hunt, O.J., and D.G. Miller. 1965. Coleoptile length, seed size, and emergence in intermediate wheatgrass (Agropyron intermedium [Host.] Beauv.). Agron. J. 57:192-195.

Jones, T.A., D.C. Nielson, and J.R. Carlson. 1991. Developing a grazingtolerant native grass for bluebunch wheatgrass sites. Rangelands $13: 147-150$.

Kneebone, W.R., and C.L. Cremer. 1955. The relationship of seed size to seedling vigor in some native grass species. Agron. J, 47:472-477.

Kitchen, S.G., and S.E. Meyer. 1991. Seed dormancy in two species of mountain mahogany (Cercocarpus ledifolius and Cercocarpus montanus). In: K.L. Johnson (ed.) Proc. 5th Utah shrub ecology workshop. The genus Cercocarpus, 27-42. Utah State Univ., Logan.

Lawrence, T. 1963. A comparison of methods of evaluating Russian wildrye for seedling vigor. Can. J. Plant Sci. 43:307-312.
Maguire, J.D. 1962. Speed of germination-aid in selection and evaluation for seedling emergence and vigor. Crop Sci. 2:176-177.

McArthur, E.D., S.E. Meyer, and D.J. Weber. 1987. Germination rate at low temperature: rubber rabbitbrush population differences. J. Range Manage. 40:530-533.

McKell, C.M. 1972. Seedling vigor and seedling establishment. p. 74-89. In: C.M. McKell and V.B. Youngner (eds.). The biology and utilization of grasses. Academic Press, New York and London.

Meyer, S.E., E.D. McArthur, and G.L. Jorgensen. 1989. Variation in germination response to temperature in rubber rabbitbrush (Chrysothamnus nauseosus: Asteraceae) and its ecological implications. Amer. J. Bot. 76:981-991.

Meyer, S.E., and S.B. Monsen. 1991. Habitat-correlated variation in mountain big sagebrush (Artemisia tridentata spp, vaseyana) seed germination patterns. Ecology 72:739-748.

Murphy, R.P., and A.C. Arny. 1939. The emergence of grass and legume seedlings planted at different depths in five soil types. J. Amer. Soc. Agron. 31:17-28.

Nelson, J.A., A.M. Wilson, and C.J. Goebel. 1970. Factors influencing broadcast seedling in bunchgrass range. J. Range Manage. 23:163-170.

Rogler, G.A. 1954. Seed size and seedling vigor in crested wheatgrass. Agron J. 46:216-220.

Tossell, W.E. 1960. Early seedling vigor and seed weight in relation to breeding in smooth bromegrass, Bromus inermis Leyss. Can. J. Plant Sci. 40:268-280.

Vogel, W.G. 1963. Planting depth and seed size influence emergence of beardless wheatgrass seedlings. J. Range Manage. 16:273-274. 